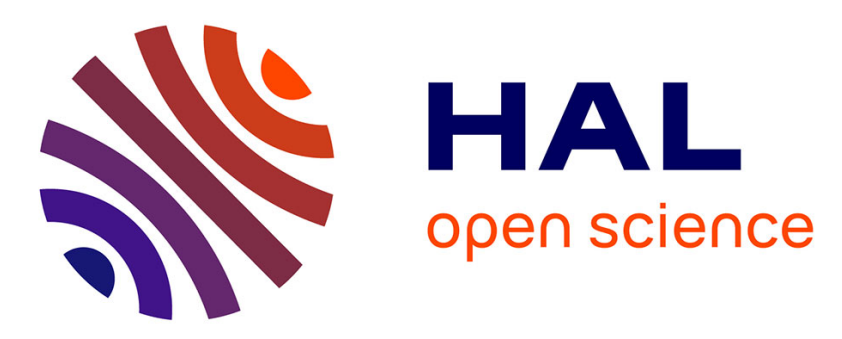

\title{
The global distribution of protected areas management strategies and their complementarity for biodiversity conservation
}

\author{
Ruppert Vimal, Laetitia M Navarro, Yanna Jones, Florian Wolf, Gilles Le \\ Moguédec, Maxime Réjou-Méchain
}

\section{To cite this version:}

Ruppert Vimal, Laetitia M Navarro, Yanna Jones, Florian Wolf, Gilles Le Moguédec, et al.. The global distribution of protected areas management strategies and their complementarity for biodiversity conservation. Biological Conservation, 2021, 256, 9 p. 10.1016/j.biocon.2021.109014 . hal-03161761

\author{
HAL Id: hal-03161761 \\ https://hal.science/hal-03161761
}

Submitted on 27 Oct 2021

HAL is a multi-disciplinary open access archive for the deposit and dissemination of scientific research documents, whether they are published or not. The documents may come from teaching and research institutions in France or abroad, or from public or private research centers.
L'archive ouverte pluridisciplinaire HAL, est destinée au dépôt et à la diffusion de documents scientifiques de niveau recherche, publiés ou non, émanant des établissements d'enseignement et de recherche français ou étrangers, des laboratoires publics ou privés. 


\title{
The global distribution of protected areas management strategies and their complementarity for biodiversity conservation R. Vimal, L. Navarro, Y. Jones, F. Wolf, G. Le Moguédec, M. Réjou-Méchain
}

\begin{abstract}
Over the last decades, massive efforts have been made to both assess and increase the amount of land dedicated to biodiversity conservation. Less is known, however, about the diversity of management strategies implemented across the network of protected areas. In this study, we used a large database of more than 175,000 global terrestrial protected areas and the distributional data of non-marine mammals, amphibians and birds to assess both the relative proportion of land covered by different IUCN management categories across regions and their potential contribution to protecting biodiversity. We show that, although at least $41 \%$ of the terrestrial protected land is managed via a strict control of human activities to conserve wild areas, $13 \%$ is dedicated to particular species or habitats often requiring active management and 25\% preserves both natural and cultural values and promotes the sustainable use of resources. Our analysis further suggests that protected areas associated with a more "human friendly” management are potentially as important as strictly-protected areas for the preservation of mammals, amphibians and birds. We argue that integrating the diversity of management strategies into conservation planning is a crucial step towards the successful preservation of the earth's biosphere.
\end{abstract}

Keywords: Protected areas, Biodiversity, Irreplaceability, IUCN management categories

\section{INTRODUCTION}


The global network of protected areas (PAs) is the cornerstone of conservation policies for the reduction of biodiversity loss (Bruner et al., 2001; Gray et al., 2016a; Rodrigues et al., 2004a). However, despite sharing this common objective, PAs vary considerably within and among regions in terms of governance, ownership, and management and can thus contribute to various alternative goals including tourism and community development, climate change mitigation, poverty alleviation, the preservation of indigenous cultures and the sustainable use of resources (Cabral et al., 2020; Leroux et al., 2010; Shafer, 2015). Protected areas encompass designations as diverse as for instance national park, indigenous reserve, game refuge, wildlife sanctuary or voluntary conservation area, to name a few.

The Convention on Biological Diversity (CBD) and its Parties have engaged in increasing the PAs coverage to at least $17 \%$ of the world terrestrial land by 2020 (CBD, 2011) and this effort is very likely to be maintained - and potentially intensified - in the post-2020 global biodiversity framework as well (CBD, 2020). For the last 20 years, under the framework of Systematic Conservation Planning, researchers have investigated gaps in the existing global network of PAs and identified spatial priorities for its extension (Margules and Pressey, 2000a; Rodrigues, 2006; Wilson et al., 2009). Thus, they predominantly focused on what and where to protect (e.g. Brum et al., 2017; Butchart et al., 2010; Dinerstein et al., 2017; Oliveira et al., 2017; Runge et al., 2015) and less on how to achieve this goal (e.g. Geldmann et al., 2018; Leverington et al., 2010). The priority should now shift from considering a landscape as binary, i.e. protected or not (Wilson et al., 2010), towards highlighting the full diversity of existing protected areas. Over the last decades, the prevailing views of nature, its relationship with humans and their activities, and the resulting approaches to conservation have changed from a focus on species and wilderness that excludes humans to a focus on ecosystem functions and services that 
integrates both people and nature (Mace, 2014). Accordingly, the concept of PA itself has evolved (Palomo et al., 2014). The dominant view of pristine, central state-controlled PAs began to change into what researchers referred to a paradigm shift (Hulme and Murphree, 1999; Locke and Dearden, 2005). This is illustrated for instance by the establishment in the 1970s of the Man and the Biosphere Programme of the UNESCO and the implementation of Biosphere Reserves (Coetzer et al., 2014). Protected areas have been increasingly expected to provide benefits to local people as well to integrate local activities into their management. Nowadays, the global network of PAs reflects this evolution and management regimes range from "fortress" to community conservation (Galvin and Haller, 2008), from strict to multi-use approach (Nelson and Chomitz, 2011) or from exclusionary protection to sustainable utilization (Andrade and Rhodes, 2012). The most recent definition of PAs adopted by the IUCN is meant to embrace this plurality. A protected area is a "clearly defined geographical space, recognized, dedicated and managed, through legal or other effective means, to achieve the long-term conservation of nature with associated ecosystem services and cultural values” (Dudley, 2008; Dudley et al., 2010). In response to a need for a common nomenclature allowing assessment and comparison between PAs within and across regions, the IUCN proposed a classification according to their management objectives into six categories. The IUCN categories give information on the specific objectives of a PA and the approach intended and needed to achieve those. They reflect a gradient towards an increased tolerance for human activities and range from strict nature reserves and wilderness areas (categories Ia and Ib) to protected areas with sustainable use of natural resources (category VI).

Such categorization of PAs coupled with the establishment of the World Database of Protected Areas (WDPA) paved the way for numerous studies that explored the relationship between 
management and human pressure (e.g. Geldmann et al., 2014; Jones et al., 2018; Leberger et al., 2020; Nagendra, 2008), between management and biodiversity trends (e.g. Coetzee et al., 2014;

Gray et al., 2016b), or between management and human livelihood (Naughton-Treves et al., 2005; Oldekop et al., 2015). Interestingly, those studies tend to show that there is no linear relationship (if any) between the degree of strictness in the management of PAs and the measured outcomes. For instance, Leroux et al. (2010) established that there was a global mismatch between the IUCN category and the degree of human impact, measured by the human footprint indicator within PAs: categories Ib and III were less impacted than categories Ia and II, and category VI was less impacted than categories IV and V. Gray et al. (2016b) found no significant differences between the IUCN categories according to four local biodiversity metrics (i.e. species richness, abundance, endemicity and rarefied richness). Nevertheless, a correlation exists between the biophysical properties of an area and its management, with stricter protection typically designated in areas of higher altitude, lower accessibility and steeper slopes when compared to other categories (Joppa and Pfaff, 2009).

Surprisingly, however, little has been said regarding the complementarity of different management categories or more broadly of different types of protected areas (Leménager et al., 2014). Complementarity is a core concept in systematic conservation planning and highlights the need to consider the extent to which an area contributes to adding unrepresented features to another area (Kukkala and Moilanen, 2013; Margules and Pressey, 2000a). The recent "protected planet reports” (UNEP-WCMC et al., 2018; UNEP-WCMC and IUCN, 2016) briefly mentions the relative distribution of PAs within the different IUCN categories but does not provide a detailed analysis of the potential of these categories to contribute to conservation goals. 
In this paper, we assess the complementarity of different management strategies of PAs based on their spatial distribution and their relative importance for the biodiversity that they are meant to protect. Rather than trying to explain their effectiveness or to provide normative views regarding how PAs should best be managed, we highlight their shared responsibility at different scales.

\section{METHODS}

\subsection{Data used}

Information on 221,503 polygons and multi-polygons considered as PAs were extracted from the World Database on Protected Areas (IUCN and UNEP WCMC, 2019). For the purpose of this study, we focused on terrestrial PAs for which the designation types were "National" and the status "Designated” and excluded all PAs associated with "International” or "Regional” designation types and "Proposed” status. We also removed duplicates, fixed some of the geometries and did not consider PAs entirely overlapping with other (see supplementary information). After these operations, we obtained a total of 176,904 terrestrial PAs (Fig. 1, Table S1).

Data on species' distribution were obtained from the IUCN Red List of Threatened Species (IUCN, 2017) and BirdLife International (BirdLife International and Handbook of the Birds of the World, 2018). For the purpose of this study, we focused on non-marine mammals $(n=5424)$, amphibians ( $n=6564)$ and birds $(n=10936)$ that are neither extinct (EX) nor extinct in the wild (EW) (Table 1).

Following Saout et al. (2013), we included only the ranges of species considered as "extant” or “probably extant” (presence codes 1 and 2) and as native (origin codes 1 and 2). Furthermore, for 
birds, only areas where species occur as "resident", "breeding”, or "non-breeding” were included (seasonality codes 1 to 3 ).

\subsection{Protected areas management categories}

Since 2002, the attribution of IUCN categories to the PAs is strictly provided by national agencies. IUCN management categories differ from each other in relation to their management focus and accordingly with regard to both the human activities allowed inside the PA (e.g. resource extraction, tourism) and the degree of intervention authorized to restore or to maintain the habitats within the PA (i.e. from active to passive) (Chape et al., 2005; Dudley, 2008, see Table 2).

In this study, we clustered the IUCN management categories into three classes (Table 2). Categories I-III PAs (n=32,959) promote nature conservation via a strict control of human activities. Such PAs aim at preserving the structure, composition and functions of ecosystems or natural monuments. They mostly target high levels of naturalness but also consider spiritual and cultural values. The level of human intervention is typically null to minimal. Human activities are prohibited, with the exception of those associated with the subsistence of local and indigenous communities, and with traditional lifestyles. Tourism requires strict control to avoid any degradation. These areas are also valuable in terms of recreation, education and scientific $130 \quad$ research.

Category IV PAs $(n=53,595)$ aim to preserve and restore fragments of ecosystems often in relation with cultural land uses. They are usually small-sized and focus on maintaining and conserving designated natural and semi-natural habitats or populations of specific species and their requirements. Protected areas in category IV often require proactive management of the 
semi-natural habitats associated with cultural landscapes. Tourism is allowed and resource extraction might occur. Those PAs can also serve for education, research and recreation. Categories V-VI PAs ( $\mathrm{n}=49,356)$ promote sustainable development and the co-existence of human activities and nature conservation. Such PAs aim to implement conservation while allowing the sustainable use of natural resources, following traditional and cultural land and sea uses. The main objective of PAs of categories V-VI is to maintain a balance between nature conservation, human well-being and economic development. Resource extraction such as forestry, farming, mining and fishing is allowed, and ecotourism is often highly promoted. An additional category "Not Reported" (n=40,994) combines all PAs for which none of the IUCN categories was informed.

145 Combining the six IUCN categories into three broader classes allowed us to mitigate the fact that different countries may allocate different categories to similarly managed PAs, and, inversely, that PAs labeled under the same category might be managed slightly differently from one country to the other (see supplementary information for detailed description of the potential limits of our approach).

$150 \quad 2.3$ Irreplaceability

The irreplaceability reflects the relative importance of an area regarding its contribution to nature preservation. Originally, irreplaceability was used in Systematic Conservation Planning as "the potential contribution of a site to a reservation goal” (Margules and Pressey, 2000b) in order to identify and select new sites to be included in a PAs network. Using the same principle, Saout et 155 al., (2013) proposed an alternative version of the irreplaceability as the measure of the actual contribution to biodiversity conservation of an area that is already designated as protected. Here we calculated an irreplaceability index inspired by the one developed by Saout et al. (2013) but 
correcting for some limitations (see supplementary information) and giving higher weights to threatened species and to species poorly represented in the global PAs network. The irreplaceability index for a given protected area, $I_{p}$, is of the form:

$$
I_{p}=\sum_{i} \Lambda_{i, p} \times \sigma_{i}
$$

Where $\sigma_{i}$ is a coefficient varying according to the IUCN threat category of species $i$ (i.e. from “Data Deficient” to “Critically Endangered”, see supplementary information) and $\Lambda_{\mathrm{i}, \mathrm{p}}$ represents the irreplaceability of species $i$ in protected area $p$ calculated as follows:

$$
\Lambda_{i, p}=\left(\omega_{i, p} \times c_{1}\right)+\left(\tau_{i, p} \times c_{2}\right)
$$

Where $\omega_{i, p}$ represents the proportion of the distribution of species $i$ covered by protected area $p$ and $\tau_{i, p}$ represents the proportion of the "protected" distribution (i.e. the global distribution of the species that falls within the global PAs network) of species $i$ covered by protected area $p$. The use of $\tau_{i, p}$ thus gives more weight to species mostly protected by a single PA. $\omega_{i, p}$ and $\tau_{i, p}$ and so that $\Lambda_{i, p}$ ranges from 0 to 1 . Note that the alternative multiplicative form $\Lambda_{i, p}=\omega_{i, p_{1}^{c_{1}}} \times \tau_{i, p^{c_{2}}}$ gave similar results (not shown). The final index $I_{p}$ was calculated for all taxa combined and for each taxonomic group (mammals, amphibians and birds), separately.

\subsection{Analysis}

In this paper, the complementarity between different management categories was assessed following two approaches. First, we calculated basic statistics for each PA such as the average surface and human footprint (Venter et al., 2016) as well as the distribution of the PAs within the different management categories globally and per subcontinent (Table 3 and Fig. S2). Following 
the approach of Watson et al. (2014), we calculated and mapped the proportion of each ecoregion covered by the different management categories (Fig. 3 and Table S2 for detailed statistics on each ecoregion).

Second, we compared the irreplaceability score between different management categories. Given that the purpose of this study was to understand the differences in irreplaceability between PAs of different management categories in similar geographical conditions, we stratified our statistical tests by ecoregions and subcontinents (see Fig. S2 for the delimitation of subcontinents). This stratification resulted in 797 spatial units worldwide corresponding to unique combinations between subcontinents and ecoregions where PAs were found (note that few ecoregions can overlap with more than one subcontinent). We fitted simple linear models, independently within each spatial unit. The model was built as follows: $\log (I(p))=\alpha+\beta \cdot \log \left(A_{p}\right)+\gamma\left(\right.$ Cat $\left._{p}\right)+\varepsilon_{p}$ where $p$ is a protected area, $I_{p}$ its irreplaceability, $A_{p}$ its area, and Cat ${ }_{p}$ its management category (I-III, IV, V-VI). We arbitrarily considered the category I-III as the reference in the ANalysis Of VAriance (i.e. the parameter $\gamma_{I-I I I}$ was set to zero) so that the parameters to be estimated are hence $\gamma_{I V}$ and $\gamma_{V-V I}$ and express the deviation of irreplaceability values in categories IV and V-VI relative to categories I-III while differences between categories IV and V-VI remain directly interpretable. The residual $\varepsilon_{\mathrm{p}}$ corresponds to the residual of the model following the usual hypotheses of a classical linear model. We fitted the model using a logtransformation for $I_{p}$ because its distribution was highly skewed, with a few very large values that led to a non-gaussian form of the residuals. We also considered the effect of the area $(A)$ in a $\log$ scale as to control the fact that $I_{p}$ is expected to increase with $A$ only through a larger 
sampling effect. Protected areas of category "Not Reported" were excluded in this part of the analysis.

The analysis was conducted for all species and for each taxonomic group separately (Fig. S3). To ensure the robustness of our results, we also compared our results with those obtained when using other forms of the irreplaceability index (i.e the index of Saout et al (2013) as well as an alternative form where the threat coefficients $\sigma$ was set to 1 for all species) (Fig. S4).

\section{RESULTS}

After processing the WDPA, we estimated that terrestrial nationally designated PAs represent $17,424,082 \mathrm{~km}^{2}$, hence $13,3 \%$ of the world land surface.

As of 2019, we identified 20\% of PAs as categories I-III, covering $41 \%$ of the PAs network. PAs of categories I-III cover a wide range of sizes but most often target pristine locations with lower levels of human activities as measured by the human footprint (Table 3). They are still the cornerstone of wildlife conservation, especially in North America, Central and Western Europe and South East Asia where they represent 64\%, 66\% and 56\% of the total protected area respectively. As a symbol of such pristine nature, the "Kahuzi-Biega National Park" (category II) in the Democratic Republic of Congo (Fig. 2) is listed in the top 200 most irreplaceable PAs in the world (Table S1) and hosts the endemic and critically endangered eastern lowland gorilla (Gorilla beringei graueri).

In contrast, by focusing on specific species and/or habitats, the implementation of PAs of category IV allows the protection of generally smaller areas often distributed among fragmented landscapes (Table 3). Within such PAs, human activities might be either highly regulated, tolerated or promoted, depending on the requirement of the targeted ecosystem. Although they represent only $13 \%$ of the global protected surface, their number is quite high, particularly in 
Central and West Asia and in Eastern Europe where they represent more than $60 \%$ of the total number of PAs (Table 3).

Finally, the co-existence between human and nature promoted by PAs of categories V-VI explains their ability to cover large areas often in human dominated landscapes with a relatively higher human footprint (Table 3). In 2019, PAs of categories V-VI represented 25\% of the global protected surface and more than $40 \%$ in Central America and Oceania. In addition to areas that drastically limit human activities, PAs such as the "Hula Nature Reserve” in Israel (category IV) and “Los Tuxtlas” in Mexico (category VI) also represent flagship areas of conservation worldwide (Fig. 2 and Table S1). The Hula Nature Reserve was created to restore and protect the wetlands that were drained for the expansion of farmland in the 1950s. These wetlands are an important stopover for migrating birds and are also home to the critically endangered Hula painted frog (Latonia nigriventer). Los Tuxtlas is an exemplar of category VI, where aside from the conservation of emblematic and endangered species such as the endemic long-tailed sabrewing (Campylopterus excellens), the Biosphere Reserve also preserves indigenous traditions and promotes sustainable uses of resources (e.g. fishing, agroforestry) by local communities. Management categories are not distributed uniformly across the sub-continental regions and also show disparities among ecoregions (Fig.3). For instance, some ecoregions within part of Europe and of Oceania are poorly covered by categories I-III and IV in contrast with categories V-VI. However, despite such patterns, our results show that, overall, different management categories largely co-exist within each ecoregion. Over the 266 ecoregions (out of 814) for which the area protected is superior or equal to $17 \%$ (Table S2, Fig 3), most encompass a balance of 
management categories and only a few $(n=30)$ are exclusively protected by one category type (categories I-III n=27, category IV n=1, categories V-VI n=2).

Furthermore, our results show that PAs with strict protection and those allowing more active management and/or human activities have a similar responsibility in terms of the biodiversity they host per unit area. Indeed, across most ecoregions, when the effect of the area of PAs is controlled for, the irreplaceability of categories IV and V-VI is not overall different from the irreplaceability of categories I-III (Fig. 4, Table S3). Nonetheless, our study also reveals different patterns at both the ecoregion and sub-continental levels with the irreplaceability of categories IV and V-VI being either lower or higher than categories I-III. For instance, in the "Humid Chaco transboundary” ecoregion of Argentina, PAs of categories IV and V-VI have a significantly lower irreplaceability than PAs of categories I-III (Table S3). In contrast, in the "Azores temperate mixed forests” in Europe, the irreplaceability is higher for categories IV and V-VI than for categories I-III. At the sub-continental level, categories V-VI have a lower irreplaceability than categories I-III in Africa and in South-East Asia, while in the latter, category IV has a higher irreplaceability than categories I-III (Fig. 4).

The analyses conducted per taxonomic group also reveals spatial disparities between management categories of PAs and their irreplaceability for mammal, amphibian and bird species (Fig. S3). For instance, in South-East Asia, PAs of category IV have a higher irreplaceability than PAs of categories I-III for mammals and birds but not for amphibians. PAs of category V-VI in Africa and in Eastern Europe seem to be of lower importance than other categories for the preservation of birds. Similarly, in Africa, PAs of category IV have a lower importance for amphibians than PAs of other categories.

\section{DISCUSSION}


Our study highlights the complementarity and the shared responsibility of different management strategies of PAs in terms of both the proportion of land they cover and the biodiversity they host.

While previous studies have focused on the extent to which the current network of PAs is on track to reach the CBD target of $17 \%$ of terrestrial land under protection status by 2020 (e.g. Watson et al., 2014), here we highlight how different management categories contribute to this goal. Overall, our results suggest that both the number and surface of PAs arise from the complementarity between different management strategies at both the ecoregion and subcontinental levels. For instance, leaving aside the non-reported PAs, PAs with the strictest protection tend to be on average larger in area, in contrast with PAs of category IV whose management type allow to establish more areas, albeit smaller, included in closer vicinity to human populations and activities (Table 3). In accordance with the results of Zimmerer et al. (2004), we show that the categories are not distributed uniformly across the global PAs network. Regional differences might be driven by complex combinations of factors related to historical, geographical, social or economic contexts (Jones-Walters and Čivić, 2013; Joppa and Pfaff, 2009). For instance, the presence of large, undisturbed and wild areas in North America might have facilitated the emergence of categories I-III PAs under the concept of "wilderness" while in contrast, the high level of human density and of fragmented landscapes in Europe might explain its high number of category IV PAs. The prevalence of strictly protected areas in South-East Asia might be partly related to its colonial history (Déry and Vanhooren, 2011; Domínguez and Luoma, 2020) while in Central America, the spatial congruences between indigenous territories and biodiversity hotspots (Berkes, 2009; Stevens, 2014) probably influenced the implementation of categories V-VI PAs. 
Different studies focused on analyzing the efficiency of different management categories in preserving biodiversity (e.g Coetzee et al., 2014; Nolte et al., 2013). Here, we rather demonstrate the shared responsibility and the complementarity of those categories towards protecting irreplaceable sites for birds, mammals and amphibians. We show that overall, in most regions of the world, the irreplaceability of PAs does not considerably vary from one management category to another one (Fig. 4). This result does not mean that biodiversity is equally preserved in all categories but that given the actual distribution range of animal species, all categories, if well managed, have the potential to preserve important biodiversity areas. Nonetheless, our results also reveal spatial patterns at both the ecoregion and continental levels with different management categories having different irreplaceability, including for different taxonomic groups (Fig. 4 and Fig. S3). Such result contributes to highlight the fact that no global hierarchy can be made between the different management categories regarding their potential role for for biodiversity conservation. Rather, their relative contribution to conservation must be assessed according to each taxonomic group in each geographical context.

Although it is widely accepted that the world's protected surface must increase to face global environmental changes, understanding the complementary between different management strategies is still a major issue. Nature conservation policies are implemented through complex combinations of ecological, social, economic, political and cultural issues (Brechin et al., 2010; Gavin et al., 2018; West et al., 2006). It is now crucial to understand how, across distinct geographical contexts, different factors shape the choice of different management strategies, and how in return different management strategies perform and respond to different objectives. While PAs dedicated to strict nature protection must remain at the forefront of conservation strategies, we showed that alternatively managed areas, more embedded with human activities, 
315 do have a high potential for protecting biodiversity as illustrated by both their spatial extent and their comparable irreplaceability (Fig. 3 and Fig. 4). Such PAs of categories IV to VI could offer relevant alternatives to protect fragmented and/or human dominated landscapes and increase the network’s robustness towards maintaining key ecological processes. Although their efficiency in maintaining biodiversity on the long term still needs to be demonstrated, we argue that such performance is entirely related to our capacity to fully acknowledge and support the management strategies that these PAs rely on (Corrigan et al., 2018). This is particularly true in regions where such strategies, as shown in our results, cover a high proportion of the protected land and/or have a higher responsibility than others.

\section{CONCLUSION}

325 Over the last decades, the assessment of the world protected areas network has been multipurposed (Maxwell et al., 2020; Rodrigues and Cazalis, 2020) and included not only the evaluation of the design (e.g. coverage of species and ecoregions, PAs connectivity) but also the evaluation of the input (e.g budget or capacity shortfalls), of the threat reduction (e.g. change in human pressures, pollution), and of the outcome (e.g. change in species abundance, socio-

330 economic benefits). We argue that such evaluations should now be conducted in light of the diversity of management strategies implemented across the protected areas network.

The CBD has invited decision makers, scientists and practitioners to reflect on and propose the scope and content of the post-2020 global biodiversity framework (CBD, 2020). In this context, new targets directly addressing spatial planning and the expansion of the protected area network should explicitly integrate the importance of the diversity of management strategies. The successful combination of these strategies will be critical to both operate the balance and find synergies between effective biodiversity conservation and human well-being. 


\section{REFERENCES}

Andrade, G.S., Rhodes, J.R., 2012. Protected areas and local communities: An inevitable partnership toward successful conservation strategies? Ecology and Society 17, 14.

Berkes, F., 2009. Community conserved areas: policy issues in historic and contemporary context. Conservation Letters 2, 20-25. https://doi.org/10.1111/j.1755-263X.2008.00040.x

BirdLife International and Handbook of the Birds of the World, 2018. Bird species distribution maps of the world. Version 2018.1. Available at http://datazone.birdlife.org/species/requestdis.

Brechin, S.R., Murray, G., Mogelgaard, K., 2010. Conceptual and Practical Issues in Defining Protected Area Success: The Political, Social, and Ecological in an Organized World. Journal of Sustainable Forestry 29, 362-389. https://doi.org/10.1080/10549810903550811

Brum, F.T., Graham, C.H., Costa, G.C., Hedges, S.B., Penone, C., Radeloff, V.C., Rondinini, C., Loyola, R., Davidson, A.D., 2017. Global priorities for conservation across multiple dimensions of mammalian diversity. Proceedings of the National Academy of Sciences 114, 7641-7646. https://doi.org/10.1073/pnas.1706461114

Bruner, A.G., Gullison, R.E., Rice, R.E., Fonseca, G.A.B. da, 2001. Effectiveness of Parks in Protecting Tropical Biodiversity. Science 291, 125-128. https://doi.org/10.1126/science.291.5501.125

Butchart, S.H.M., Walpole, M., Collen, B., Strien, A. van, Scharlemann, J.P.W., Almond, R.E.A., Baillie, J.E.M., Bomhard, B., Brown, C., Bruno, J., Carpenter, K.E., Carr, G.M., Chanson, J., Chenery, A.M., Csirke, J., Davidson, N.C., Dentener, F., Foster, M., Galli, A., Galloway, J.N., Genovesi, P., Gregory, R.D., Hockings, M., Kapos, V., Lamarque, J.-F., Leverington, F., Loh, J., McGeoch, M.A., McRae, L., Minasyan, A., Morcillo, M.H., Oldfield, T.E.E., Pauly, D., Quader, S., Revenga, C., Sauer, J.R., Skolnik, B., Spear, D., Stanwell-Smith, D., Stuart, S.N., Symes, A., Tierney, M., Tyrrell, T.D., Vié, J.-C., Watson, R., 2010. Global Biodiversity: Indicators of Recent Declines. Science 328, 1164-1168. https://doi.org/10.1126/science.1187512

Cabral, R.B., Bradley, D., Mayorga, J., Goodell, W., Friedlander, A.M., Sala, E., Costello, C., Gaines, S.D., 2020. A global network of marine protected areas for food. PNAS. https://doi.org/10.1073/pnas.2000174117

CBD, 2020. Update of the zero draft of the post-2020 global biodiversity framework. CBD/POST2020/PREP/2/1, 17 August 2020. CBD Secretariat, Montreal, Canada.

CBD, 2011. Aichi Biodiversity Targets.

Chape, S., Harrison, J., Spalding, M., Lysenko, I., 2005. Measuring the extent and effectiveness of protected areas as an indicator for meeting global biodiversity targets. Philosophical Transactions of the Royal Society B: Biological Sciences 360, 443-455.

Coetzee, B.W.T., Gaston, K.J., Chown, S.L., 2014. Local Scale Comparisons of Biodiversity as a Test for Global Protected Area Ecological Performance: A Meta-Analysis. PLOS ONE 9, e105824. https://doi.org/10.1371/ journal.pone.0105824

Coetzer, K.L., Witkowski, E.T.F., Erasmus, B.F.N., 2014. Reviewing Biosphere Reserves globally: effective conservation action or bureaucratic label?: Reviewing Biosphere Reserves globally. Biol Rev 89, 82-104. https://doi.org/10.1111/brv.12044

Corrigan, C., Bingham, H., Shi, Y., Lewis, E., Chauvenet, A., Kingston, N., 2018. Quantifying the contribution to biodiversity conservation of protected areas governed by indigenous peoples and local communities. Biological Conservation 227, 403-412. https://doi.org/10.1016/j.biocon.2018.09.007

Déry, S., Vanhooren, R., 2011. Protected areas in mainland Southeast Asia, 1973-2005: Continuing trends. Singapore Journal of Tropical Geography 32, 185-202. https://doi.org/10.1111/j.1467-9493.2011.00428.x

Dinerstein, E., Olson, D., Joshi, A., Vynne, C., Burgess, N.D., Wikramanayake, E., Hahn, N., Palminteri, S., Hedao, P., Noss, R., Hansen, M., Locke, H., Ellis, E.C., Jones, B., Barber, C.V., Hayes, R., Kormos, C., Martin, V., Crist, E., Sechrest, W., Price, L., Baillie, J.E.M., Weeden, D., Suckling, K., Davis, C., Sizer, N., Moore, R., Thau, D., Birch, T., Potapov, P., Turubanova, S., Tyukavina, A., de Souza, N., Pintea, L., Brito, J.C., Llewellyn, O.A., Miller, A.G., Patzelt, A., Ghazanfar, S.A., Timberlake, J., Klöser, H., Shennan-Farpón, Y., Kindt, R., Lillesø, J.-P.B., van Breugel, P., Graudal, L., Voge, M., Al-Shammari, K.F., Saleem, M., 2017. An 
Ecoregion-Based Approach to Protecting Half the Terrestrial Realm. BioScience 67, 534-545. https://doi.org/10.1093/biosci/bix014

Domínguez, L., Luoma, C., 2020. Decolonising Conservation Policy: How Colonial Land and Conservation Ideologies Persist and Perpetuate Indigenous Injustices at the Expense of the Environment. Land 9, 65. https://doi.org/10.3390/land9030065

Dudley, N., 2008. Guidelines for applying protected area management categories. IUCN, Gland, Switzerland.

Dudley, N., Parrish, J.D., Redford, K.H., Stolton, S., 2010. The revised IUCN protected area management categories: the debate and ways forward. Oryx 44, 485-490. https://doi.org/10.1017/S0030605310000566

Galvin, M., Haller, T., 2008. People, Protected Areas and Global Change: Participatory Conservation in Latin America, Africa, Asia and Europe. Perspectives / Swiss National Centre of Competence in Research (NCCR) North-South, University of Berne, Institute of Geography ; vol. 33.

Gavin, M.C., McCarter, J., Berkes, F., Sterling, E.J., Turner, N.J., 2018. Protected land: Many factors shape success. Science 361, 561-561. https://doi.org/10.1126/science.aau5168

Geldmann, J., Coad, L., Barnes, M.D., Craigie, I.D., Woodley, S., Balmford, A., Brooks, T.M., Hockings, M., Knights, K., Mascia, M.B., McRae, L., Burgess, N.D., 2018. A global analysis of management capacity and ecological outcomes in terrestrial protected areas. Conservation Letters 11, e12434. https://doi.org/10.1111/ conl.12434

Geldmann, J., Joppa, L.N., Burgess, N.D., 2014. Mapping Change in Human Pressure Globally on Land and within Protected Areas. Conservation Biology 28, 1604-1616. https://doi.org/10.1111/cobi.12332

Gray, C.L., Hill, S.L.L., Newbold, T., Hudson, L.N., Börger, L., Contu, S., Hoskins, A.J., Ferrier, S., Purvis, A., Scharlemann, J.P.W., 2016a. Local biodiversity is higher inside than outside terrestrial protected areas worldwide. Nature Communications 7, 12306. https://doi.org/10.1038/ncomms12306

Gray, C.L., Hill, S.L.L., Newbold, T., Hudson, L.N., Börger, L., Contu, S., Hoskins, A.J., Ferrier, S., Purvis, A., Scharlemann, J.P.W., 2016b. Local biodiversity is higher inside than outside terrestrial protected areas worldwide. Nature Communications 7, 12306. https://doi.org/10.1038/ncomms12306

Hulme, D., Murphree, M., 1999. Communities, wildlife and the 'new conservation' in Africa. J. Int. Dev. 11, 277285. https://doi.org/10.1002/(SICI)1099-1328(199903/04)11:2<277::AID-JID582>3.0.CO;2-T

IUCN, 2017. The IUCN Red List of Threatened Species. Version 3, May 2017.

IUCN, UNEP WCMC, 2019. The World Database on Protected Areas (WDPA).

Jones, K.R., Venter, O., Fuller, R.A., Allan, J.R., Maxwell, S.L., Negret, P.J., Watson, J.E.M., 2018. One-third of global protected land is under intense human pressure. Science 360, 788-791. https://doi.org/10.1126/science.aap9565

Jones-Walters, L., Čivić, K., 2013. European protected areas: Past, present and future. Journal for Nature Conservation 21, 122-124. https://doi.org/10.1016/j.jnc.2012.11.006

Joppa, L.N., Pfaff, A., 2009. High and Far: Biases in the Location of Protected Areas. PLOS ONE 4, e8273. https://doi.org/10.1371/journal.pone.0008273

Kukkala, A.S., Moilanen, A., 2013. Core concepts of spatial prioritisation in systematic conservation planning: Concepts of systematic conservation planning. Biological Reviews 88, 443-464. https://doi.org/10.1111/brv.12008

Leberger, R., Rosa, I.M.D., Guerra, C.A., Wolf, F., Pereira, H.M., 2020. Global patterns of forest loss across IUCN categories of protected areas. Biological Conservation 241, 108299.

https://doi.org/10.1016/j.biocon.2019.108299

Leménager, T., King, D., Elliott, J., Gibbons, H., King, A., 2014. Greater than the sum of their parts: Exploring the environmental complementarity of state, private and community protected areas. Global Ecology and Conservation 2, 238-247. https://doi.org/10.1016/j.gecco.2014.09.009

Leroux, S.J., Krawchuk, M.A., Schmiegelow, F., Cumming, S.G., Lisgo, K., Anderson, L.G., Petkova, M., 2010. Global protected areas and IUCN designations: Do the categories match the conditions? Biological Conservation 143, 609-616. https://doi.org/10.1016/j.biocon.2009.11.018

Leverington, F., Costa, K.L., Pavese, H., Lisle, A., Hockings, M., 2010. A Global Analysis of Protected Area Management Effectiveness. Environmental Management 46, 685-698. https://doi.org/10.1007/s00267-0109564-5

Locke, H., Dearden, P., 2005. Rethinking protected area categories and the new paradigm. Environmental conservation 32, 1-10.

Mace, G.M., 2014. Whose conservation? Science 345, 1558-1560. https://doi.org/10.1126/science.1254704 
Margules, C.R., Pressey, R.L., 2000a. Systematic conservation planning. Nature 405, 243-253.

Margules, C.R., Pressey, R.L., 2000b. Systematic conservation planning. Nature 405, 243-253.

Maxwell, S.L., Cazalis, V., Dudley, N., Hoffmann, M., Rodrigues, A.S.L., Stolton, S., Visconti, P., Woodley, S., Kingston, N., Lewis, E., Maron, M., Strassburg, B.B.N., Wenger, A., Jonas, H.D., Venter, O., Watson, J.E.M., 2020. Area-based conservation in the twenty-first century. Nature 586, 217-227. https://doi.org/10.1038/s41586-020-2773-z

Nagendra, H., 2008. Do Parks Work? Impact of Protected Areas on Land Cover Clearing. AMBIO: A Journal of the Human Environment 37, 330-337. https://doi.org/10.1579/06-R-184.1

Naughton-Treves, L., Holland, M.B., Brandon, K., 2005. The role of protected areas in conserving biodiversity and sustaining local livelihoods. Annu. Rev. Environ. Resour. 30, 219-252.

Nelson, A., Chomitz, K.M., 2011. Effectiveness of Strict vs. Multiple Use Protected Areas in Reducing Tropical Forest Fires: A Global Analysis Using Matching Methods. PLOS ONE 6, e22722. https://doi.org/10.1371/journal.pone.0022722

Nolte, C., Agrawal, A., Silvius, K.M., Soares-Filho, B.S., 2013. Governance regime and location influence avoided deforestation success of protected areas in the Brazilian Amazon. PNAS 110, 4956-4961. https://doi.org/10.1073/pnas.1214786110

Oldekop, J.A., Holmes, G., Harris, W.E., Evans, K.L., 2015. A global assessment of the social and conservation outcomes of protected areas. Conservation Biology n/a-n/a. https://doi.org/10.1111/cobi.12568

Oliveira, U., Soares-Filho, B.S., Paglia, A.P., Brescovit, A.D., de Carvalho, C.J.B., Silva, D.P., Rezende, D.T., Leite, F.S.F., Batista, J.A.N., Barbosa, J.P.P.P., Stehmann, J.R., Ascher, J.S., de Vasconcelos, M.F., De Marco, P., Löwenberg-Neto, P., Ferro, V.G., Santos, A.J., 2017. Biodiversity conservation gaps in the Brazilian protected areas. Scientific Reports 7, 9141. https://doi.org/10.1038/s41598-017-08707-2

Palomo, I., Montes, C., Martín-López, B., González, J.A., García-Llorente, M., Alcorlo, P., Mora, M.R.G., 2014. Incorporating the Social-Ecological Approach in Protected Areas in the Anthropocene. BioScience bit033. https://doi.org/10.1093/biosci/bit033

Rodrigues, A.S.L., 2006. Are global conservation efforts successful? Science 313, 1051-1052.

Rodrigues, A.S.L., Akçakaya, H.R., Andelman, S.J., Bakarr, M.I., Boitani, L., Brooks, T.M., Chanson, J.S., Fishpool, L.D.C., Fonseca, G.A.B., Gaston, K.J., Hoffmann, M., Marquet, P.A., Pilgrim, J.D., Pressey, R.L., Schipper, J., Sechrest, W., Stuart, S.N., Underhill, L.G., Waller, R.W., Watts, M.E.J., Yan, X., 2004. Global gap analysis: Priority regions for expanding the global protected-area network. BioScience 54, 1092-1100.

Rodrigues, A.S.L., Cazalis, V., 2020. The multifaceted challenge of evaluating protected area effectiveness. Nature Communications 11, 5147. https://doi.org/10.1038/s41467-020-18989-2

Runge, C.A., Watson, J.E.M., Butchart, S.H.M., Hanson, J.O., Possingham, H.P., Fuller, R.A., 2015. Protected areas and global conservation of migratory birds. Science 350, 1255-1258. https://doi.org/10.1126/science.aac9180

Saout, S.L., Hoffmann, M., Shi, Y., Hughes, A., Bernard, C., Brooks, T.M., Bertzky, B., Butchart, S.H.M., Stuart, S.N., Badman, T., Rodrigues, A.S.L., 2013. Protected Areas and Effective Biodiversity Conservation. Science 342, 803-805. https://doi.org/10.1126/science.1239268

Shafer, C.L., 2015. Cautionary thoughts on IUCN protected area management categories V-VI. Global Ecology and Conservation 3, 331-348. https://doi.org/10.1016/j.gecco.2014.12.007

Stevens, S. (Ed.), 2014. Indigenous peoples, national parks, and protected areas: a new paradigm linking conservation, culture, and rights. University of Arizona Press, Tucson.

UNEP-WCMC, IUCN, 2016. Protected Planet Report 2016. UNEP-WCMC and IUCN: Cambridge UK and Gland, Switzerland.

UNEP-WCMC, IUCN, NGS, 2018. Protected Planet Report 2018. UNEP-WCMC, IUCN and NGS: Cambridge UK; Gland, Switzeland; and Washington, D.C., USA.

Venter, O., Sanderson, E.W., Magrach, A., Allan, J.R., Beher, J., Jones, K.R., Possingham, H.P., Laurance, W.F., Wood, P., Fekete, B.M., Levy, M.A., Watson, J.E.M., 2016. Global terrestrial Human Footprint maps for 1993 and 2009. Scientific Data 3, 160067. https://doi.org/10.1038/sdata.2016.67

Watson, J.E.M., Dudley, N., Segan, D.B., Hockings, M., 2014. The performance and potential of protected areas. Nature 515, 67-73. https://doi.org/10.1038/nature13947

West, P., Igoe, J., Brockington, D., 2006. Parks and peoples: The social impact of protected areas. Annual Review of Anthropology 35, 251-277. 
Wildlife Conservation Society (WCS), Center for International Earth Science Information Network (CIESIN), 2005. Last of the Wild Data Version 2: Global Human Footprint Dataset (Geographic).

Wilson, K.A., Carwardine, J., Possingham, H.P., 2009. Setting Conservation Priorities. Year in Ecology and Conservation Biology 2009 1162, 237-264.

Wilson, K.A., Meijaard, E., Drummond, S., Grantham, H.S., Boitani, L., Catullo, G., Christie, L., Dennis, R., Dutton, I., Falcucci, A., Maiorano, L., Possingham, H.P., Rondinini, C., Turner, W.R., Venter, O., Watts, M., 2010. Conserving biodiversity in production landscapes. Ecological Applications 20, 1721-1732. https://doi.org/10.1890/09-1051.1

Zimmerer, K.S., Galt, R.E., Buck, M.V., 2004. Globalization and Multi-spatial Trends in the Coverage of ProtectedArea Conservation (1980-2000). AMBIO: A Journal of the Human Environment 33, 520-529. https://doi.org/10.1579/0044-7447-33.8.520

Table 1. Number of species considered and their IUCN status for each taxonomic group used in the analysis.

\begin{tabular}{lccc}
\hline IUCN Status & Amphibians & Mammals & Birds \\
\hline DD & 1399 & 735 & 52 \\
LC & 2737 & 3185 & 8405 \\
NT & 380 & 337 & 1012 \\
VU & 637 & 521 & 799 \\
EN & 903 & 466 & 469 \\
CR & 508 & 180 & 199 \\
\hline
\end{tabular}


Table 2. Categories' main characteristics (adapted from Chape et al. (2005) and Dudley (2008) Note that Categories Ia and Ib differ mostly

\begin{tabular}{|c|c|c|c|c|c|}
\hline $\begin{array}{l}\text { IUCN } \\
\text { Category }\end{array}$ & Nam e & Objectives & Management & Human activities allowed & $\begin{array}{l}\text { Category as } \\
\text { defined in } \\
\text { this study }\end{array}$ \\
\hline la & $\begin{array}{l}\text { Strict nature } \\
\text { reserve }\end{array}$ & $\begin{array}{l}\text { Conservation of natural ecosystem, } \\
\text { species, and geological features. Scientific } \\
\text { research and/or environmental monitoring }\end{array}$ & Minimum intervention for restoration & $\begin{array}{l}\text { Research and visit in the case of sacred } \\
\text { sites (limited) }\end{array}$ & \multirow{4}{*}{$I-I I I$} \\
\hline Ib & Wilderness area & $\begin{array}{l}\text { Wilderness protection (i.e. large } \\
\text { unmodified areas) and recreation } \\
\text { (secondary) }\end{array}$ & Minim um to no intervention & $\begin{array}{l}\text { Recreation, traditional wilderness based } \\
\text { activities, research, education }\end{array}$ & \\
\hline II & National park & $\begin{array}{l}\text { Ecosystem protection (i.e. maintenance of } \\
\text { large scale ecological processes) and } \\
\text { recreation }\end{array}$ & $\begin{array}{l}\text { Minimum intervention. Those areas are } \\
\text { subject to zoning and a higher tolerance to } \\
\text { human use can be observed in the } \\
\text { surrounding bufferzones }\end{array}$ & $\begin{array}{l}\text { Tourism, recreation, education, research, } \\
\text { subsistence resource use for indigeneous } \\
\text { and local communities }\end{array}$ & \\
\hline III & $\begin{array}{l}\text { Natural } \\
\text { monument or } \\
\text { feature }\end{array}$ & $\begin{array}{l}\text { Conservation of specific natural features } \\
\text { (e.g. landform, submarine cavern, ancient } \\
\text { grove) and the associated species and } \\
\text { habitats }\end{array}$ & $\begin{array}{l}\text { Intervention targeted to particular natural } \\
\text { features (overall similar to the } \\
\text { management of category II, although at a } \\
\text { smaller scale) }\end{array}$ & Tourism, recreation, education, research & \\
\hline IV & $\begin{array}{l}\text { Habitat } / \text { species } \\
\text { management } \\
\text { area }\end{array}$ & $\begin{array}{l}\text { Conservation of specific habitats or } \\
\text { species populations of natural or cultural } \\
\text { value }\end{array}$ & $\begin{array}{l}\text { From low intervention to regular, active } \\
\text { (traditional) interventions to maintain or } \\
\text { restore specific (semi-)natural habitats or } \\
\text { species requirements }\end{array}$ & Tourism, recreation, education, research & IV \\
\hline $\mathbf{v}$ & $\begin{array}{l}\text { Protected } \\
\text { landscape/seasca } \\
\text { pe }\end{array}$ & $\begin{array}{l}\text { Conservation of areas shaped and } \\
\text { maintained by human activities and } \\
\text { recreation }\end{array}$ & $\begin{array}{l}\text { Management, including by the local } \\
\text { communities, by active intervention, } \\
\text { maintenance or restoration of the } \\
\text { (traditional) human activities that defined } \\
\text { the landscape/seascape. Note that this } \\
\text { category can actas buffers of stricter } \\
\text { protection areas }\end{array}$ & $\begin{array}{l}\text { Agriculture, forestry, fishery, development, } \\
\text { tourism, recreation, education, research }\end{array}$ & \multirow[t]{2}{*}{ V-V I } \\
\hline V I & $\begin{array}{l}\text { Protected area } \\
\text { with sustainable } \\
\text { use of natural } \\
\text { resources }\end{array}$ & $\begin{array}{l}\text { Conservation of ecosystems, ecosystem } \\
\text { services and associated cultural values, } \\
\text { and (traditional) sustainable use of its } \\
\text { natural resources }\end{array}$ & $\begin{array}{l}\text { Management to allow the maintenance of } \\
\text { natural ecosystems and resources to } \\
\text { support their sustainable use }\end{array}$ & $\begin{array}{l}\text { Sustainable extraction of natural resources } \\
\text { (including hunting, grazing), development, } \\
\text { tourism, recreation, education, research }\end{array}$ & \\
\hline
\end{tabular}


Table 3. Descriptive statistics for each management category.

\begin{tabular}{|c|c|c|c|c|c|}
\hline \multirow{4}{*}{ Africa } & $\mid-I I I$ & 5 & 29 & 7,0 & 2930,4 \\
\hline & IV & 4 & 16 & 9,5 & 2166,3 \\
\hline & $\mathrm{V}-\mathrm{VI}$ & 3 & 14 & 7,2 & 2568,5 \\
\hline & Not Reported & 88 & 41 & 10,3 & 246,8 \\
\hline \multirow{4}{*}{$\begin{array}{l}\text { Central and Western } \\
\text { Europe }\end{array}$} & I-III & 12 & 66 & 12,0 & 113,9 \\
\hline & IV & 39 & 5 & 20,0 & 3,0 \\
\hline & $\mathrm{V}-\mathrm{VI}$ & 15 & 20 & 21,7 & 28,0 \\
\hline & Not Reported & 33 & 9 & 10,6 & 6,2 \\
\hline \multirow{4}{*}{ Eastern Europe } & I-III & 25 & 33 & 8,7 & 560,0 \\
\hline & IV & 66 & 48 & 8,8 & 312,5 \\
\hline & $\mathrm{V}-\mathrm{VI}$ & 6 & 18 & 5,2 & 1224,8 \\
\hline & Not Reported & 3 & 2 & 7,3 & 335,3 \\
\hline \multirow{4}{*}{ North America } & I-III & 17 & 64 & 9,1 & 214,5 \\
\hline & IV & 9 & 17 & 3,9 & 105,3 \\
\hline & V-VI & 72 & 18 & 16,6 & 13,7 \\
\hline & Not Reported & 2 & 0 & 23,8 & 13,6 \\
\hline \multirow{4}{*}{ Central America } & I-III & 16 & 39 & 12,5 & 637,1 \\
\hline & IV & 18 & 3 & 15,5 & 46,0 \\
\hline & V-VI & 36 & 42 & 11,2 & 314,4 \\
\hline & Not Reported & 30 & 16 & 14,9 & 143,9 \\
\hline \multirow{4}{*}{ South America } & $I-I I I$ & 18 & 24 & 8,7 & 1335,7 \\
\hline & IV & 12 & 2 & 9,2 & 158,9 \\
\hline & $\mathrm{V}-\mathrm{VI}$ & 27 & 31 & 10,4 & 1139,5 \\
\hline & Not Reported & 44 & 43 & 9,8 & 963,6 \\
\hline \multirow{4}{*}{ Central and West Asia } & I-III & 10 & 42 & 11,3 & 572,8 \\
\hline & IV & 68 & 23 & 21,3 & 46,8 \\
\hline & V-VI & 19 & 27 & 18,5 & 204,7 \\
\hline & Not Reported & 3 & 8 & 15,3 & 417,3 \\
\hline \multirow{4}{*}{ South East Asia } & $\mathrm{I}-\mathrm{III}$ & 44 & 56 & 9,9 & 510,1 \\
\hline & IV & 12 & 18 & 9,0 & 640,9 \\
\hline & $\mathrm{V}-\mathrm{VI}$ & 28 & 16 & 13,9 & 236,3 \\
\hline & Not Reported & 16 & 10 & 11,5 & 246,5 \\
\hline \multirow{4}{*}{ Oceania } & I-III & 64 & 45 & 9,7 & 66,5 \\
\hline & IV & 23 & 2 & 10,7 & 6,5 \\
\hline & $\mathrm{V}-\mathrm{VI}$ & 10 & 50 & 7,9 & 460,8 \\
\hline & Not Reported & 2 & 3 & 10,0 & 129,5 \\
\hline \multirow{4}{*}{ Global } & $\mathrm{I}-\mathrm{III}$ & 19 & 41 & 10,4 & 214,4 \\
\hline & IV & 30 & 13 & 17,7 & 42,7 \\
\hline & $\mathrm{V}-\mathrm{VI}$ & 28 & 25 & 17,5 & 87,8 \\
\hline & Not Reported & 23 & 21 & 10,8 & 91,1 \\
\hline
\end{tabular}




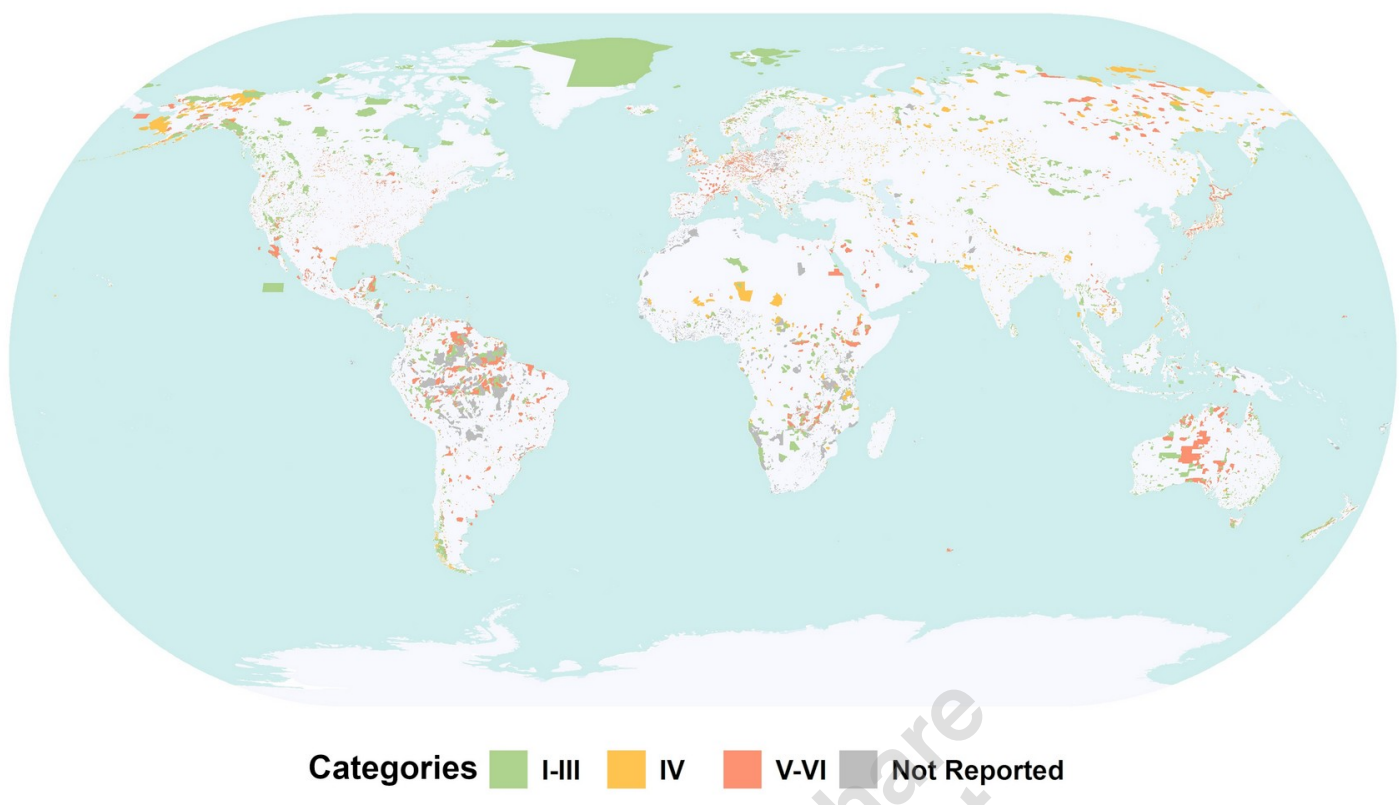

Fig. 1. The distribution of the 176,904 protected areas used in this study and their IUCN management categories. 


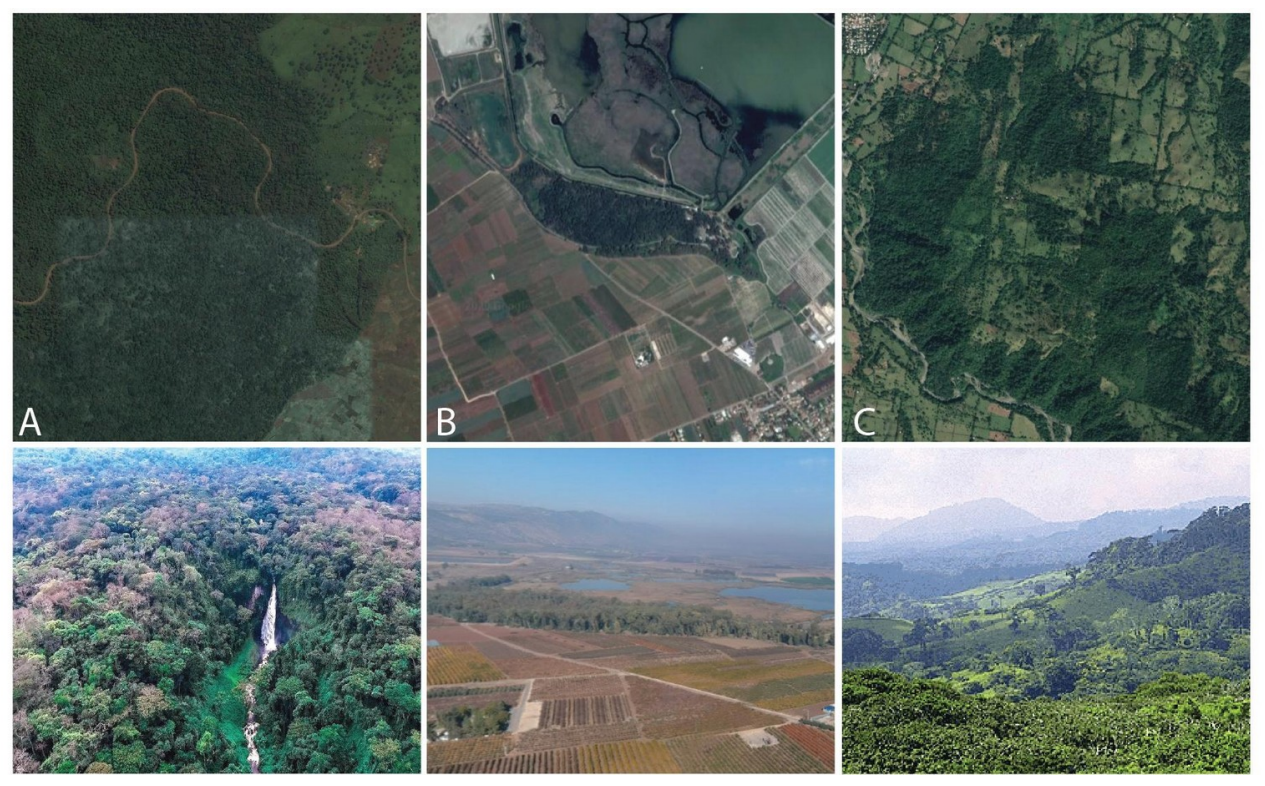

Fig. 2. Examples of protected areas from the top 200 most irreplaceable sites identified in this study : A- Kahuzi-Biega National Park in Republic Democratic of Congo (IUCN Category II); B- Hula Nature Reserve in Israel (IUCN Category IV); C- Los Tuxtlas (Zona de Amortiguamiento) in Mexico (IUCN Category VI). Copyright : Forest Service/ USDA (public domain), Google Earth, Semarnat (https://www.gob.mx/semarnat). 

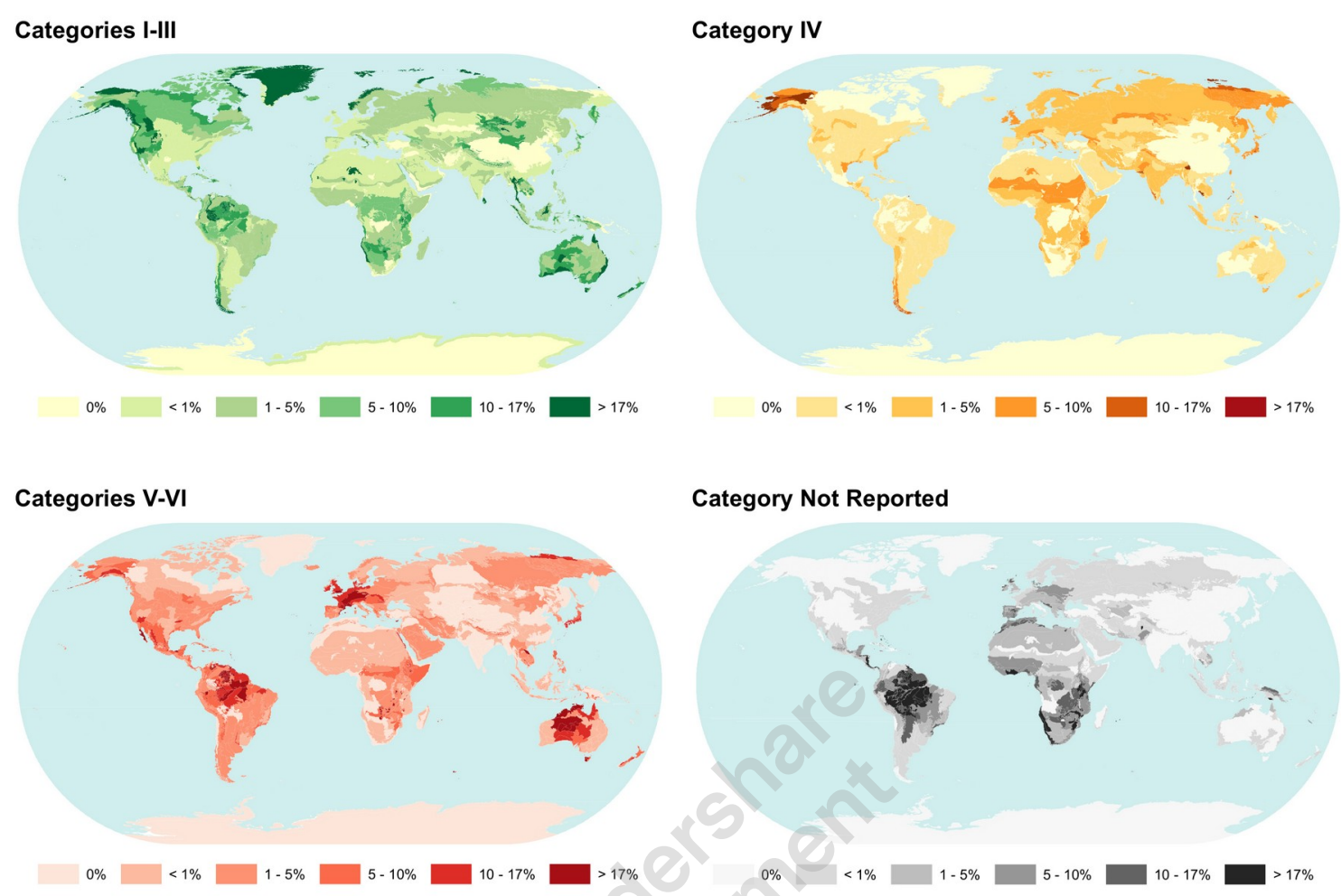

Fig. 3. Proportion of each ecoregion covered by different management categories of protected areas. The highest threshold of $17 \%$ was chosen in reference to Aichi Target 11 (CBD, 2011). 


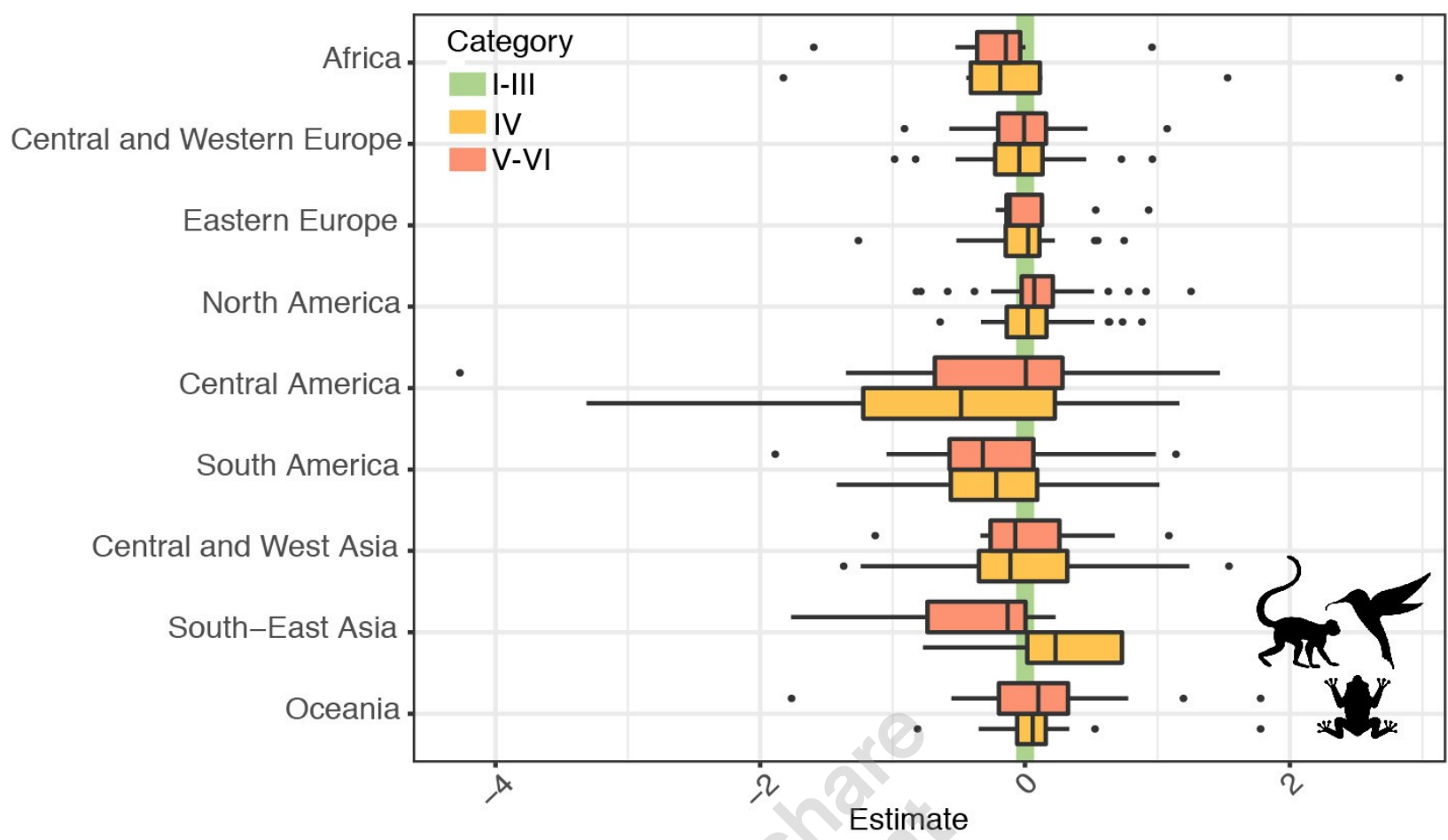

Fig. 4. Comparison of the irreplaceability of protected areas of different management categories for mammals, amphibians and birds. Linear models were fitted separately within each ecoregion controlling for the surface of protected areas. Boxplots represent the distribution, at the subcontinental level, of the model coefficients (Estimates) associated with categories IV and V-VI, (categories I-III being considered as the reference. 